\title{
Prenatal management and perinatal outcome in giant placental chorioangioma complicated with hydrops fetalis, fetal anemia and maternal mirror syndrome
}

\author{
Lutgardo García-Díaz', Práxedes Carreto², Susana Costa-Pereira and Guillermo Antiñolo 1,3,4*
}

\begin{abstract}
Background: Giant placental chorioangiomas have been associated with a number of severe fetal complications and high perinatal mortality.

Case presentation: We report a case of giant chorioangioma with fetal hydrops, additionally complicated by severe anemia, mild cardiomegaly with hyperdinamic heart circulation and maternal mirror syndrome. Intrauterine blood transfusion and amniodrainage was performed at 29 weeks. Worsening of the fetal and maternal condition prompted us to proceed with delivery at $29+5$ weeks. The newborn died 3 hours later due to pulmonary hypoplasia and hemodynamic failure. Maternal course was favourable, mirror syndrome resolved in the second day and the patient was discharged four days following delivery.

Conclusions: In the case described here, fetal condition got worse despite of the anemia correction and amniodrainage. Our outcome raises the issue whether additional intrauterine clinical intervention, as intersticial laser, should have been performed to stop further deterioration of the fetal condition when progressive severe hydrops develops.
\end{abstract}

Keywords: Fetal chorioangioma, Hydrops fetalis, Fetal anemia, Fetal therapy, Mirror syndrome

\section{Background}

Chorioangiomas are benign placenta tumors histologically corresponding either to hamartomas derived from primitive chorionic mesenchyma or placental hemangiomas arising from chorionic plate [1]. Large or giant chorioangiomas, defined as measuring more than $4-5 \mathrm{~cm}$ in diameter, have an estimated prevalence varying from one in 9000 to one in 50000 pregnancies [1], and have been associated with a number of fetal complications including anemia, polyhydramnios, hyperdynamic circulation and cardiomegaly, hydrops, and growth restriction [2-6]. In view of these complications and the associated

\footnotetext{
* Correspondence: guillermo.antinolo.sspa@juntadeandalucia.es

'Unidad de Gestión Clínica de Genética, Reproducción y Medicina Fetal. Instituto de Biomedicina de Sevilla (IBIS), Hospital Universitario Virgen del Rocío/CSIC/Universidad de Sevilla, Sevilla, Spain

${ }^{3}$ Centro de Investigación Biomédica en Red de Enfermedades Raras (CIBERER), Sevilla, Spain

Full list of author information is available at the end of the article
}

high perinatal death rate (30-40\%), a number of therapeutic interventions have been attempted with limited success in most cases $[5,7,8]$.

Here we report a case of giant chorioangioma, fetal hydrops, additionally complicated by severe anemia, mild cardiomegaly with hyperdinamic heart circulation and maternal mirror syndrome.

\section{Case presentation}

A 34-year-old woman, gravida 1, was referred to our Department at 29 weeks' gestation because of placental chorioangioma, severe hydrops fetalis, suspected fetal anemia and maternal mirror syndrome (Ballantine's syndrome), previously not detected. Ultrasound examination confirmed fetal hydrops with hydrothorax and ascitis, fetal anemia (middle cerebral artery peak systolic velocity: $74.3 \mathrm{~cm} / \mathrm{sg}$ with an estimated haemoglobin of $7.14 \mathrm{~g} / \mathrm{dl}$ ), polyhydramnios (maximum pocket 14),

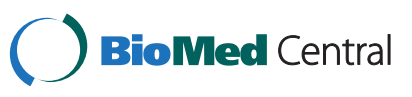


estimated fetal weight of $2460 \mathrm{~g}$ and mild cardiomegaly (cardiac area more than $1 / 3$ of thoracic area) with hyperdinamic heart circulation. In addition, ultrasound examination showed the presence of a heterogenous hypoechoic area of 70x56 mm, with color Doppler showing a specific blood supply, both consistent with diagnosis of chorioangioma (Figure 1). Maternal examination was consistent with mirror syndrome (edema, oliguria, anemia, elevated liver enzymes, hypoproteinemia and hypokalemia). Blood pressure was normal. At $29+1$ weeks, treatment with $12 \mathrm{mg}$ betamethasone injections (two doses separated in 24hours) was given; intrauterine transfusion (IUT) of $80 \mathrm{ml}$ of packed red blood cell suspension with a $70 \%$ hematocrit was performed, and followed by amniodrainage. Initial fetal hematocrit was $7 \mathrm{~g} / \mathrm{dL}$ and final one was $12 \mathrm{~g} / \mathrm{dL}$. $1800 \mathrm{ml}$ of amniotic fluid were drained, reducing maximum pocket to $5 \mathrm{~cm}$. Within the next hour preterm labor developed, therapy with atosiban and nifedipine was initiated and the contractions subsided. At $29+5$ weeks' gestation, fetal ultrasound showed worsening of the fetal hydrothorax as well as pulsatility index of the umbilical artery over $95^{\text {th }}$ centile. In addition, worsening of the maternal mirror syndrome (pleural effusion and increasing levels of liver enzymes) was noted. Worsening of the fetal and maternal condition prompted us to proceed with delivery at $29+5$ weeks'. A thoracocentesis to optimise the neonatal resuscitation was performed in the operating room, and was immediately followed by the caesarean section. The newborn weighed $2503 \mathrm{~g}$ and apgar score was 1 and 4 at 1 and $5 \mathrm{~min}$. The newborn died 3 hours later due to pulmonary hypoplasia and hemodynamic failure. Maternal course was favourable, mirror syndrome resolved in the second day and the patient was discharged four days following delivery. Histological analysis confirmed the diagnosis of placental chorioangioma (Figure 2). Microscopic examination showed that the chorioangioma

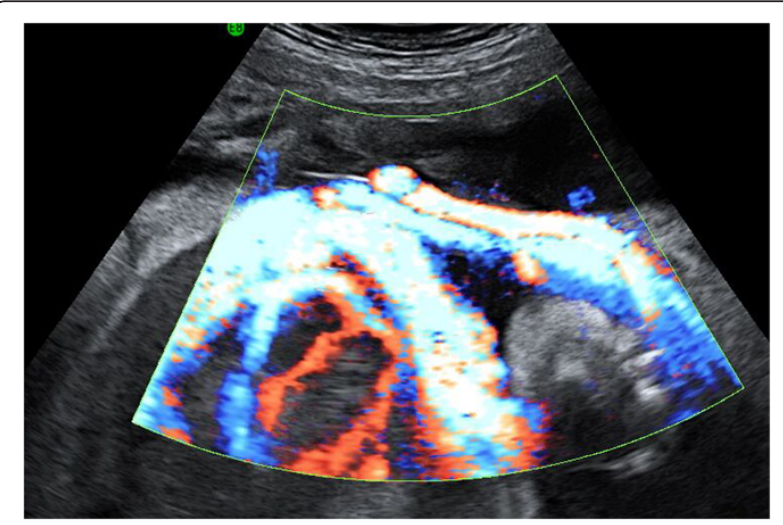

Figure 1 Color Doppler of giant placental choriangioma.

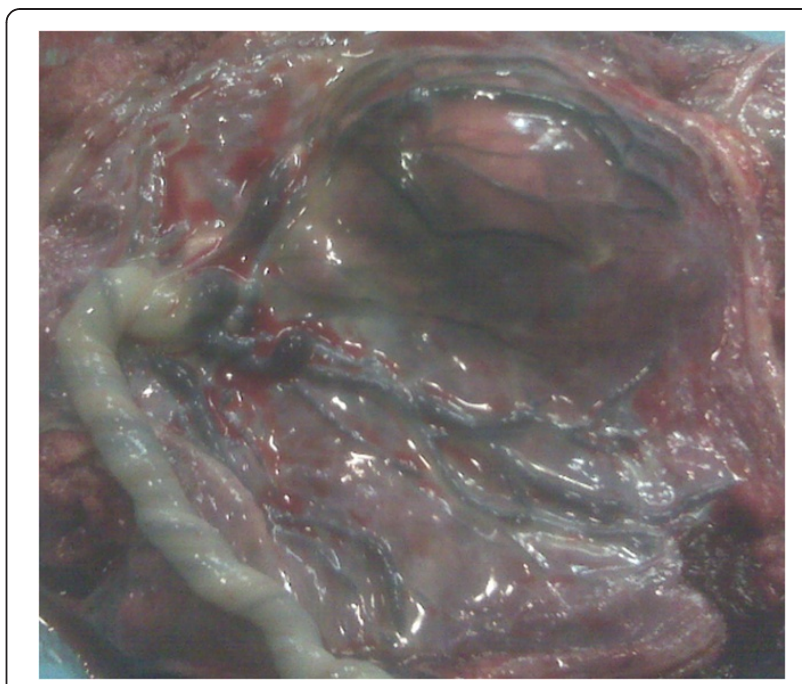

Figure 2 Macroscopic view of giant placental choriangioma.

was composed of predominantly capillary vascular areas in the fibroid matrix.

\section{Discussion}

Around 50\% of large chorioangiomas cases develop fetal and maternal complications that required either elective delivery or intervention for tumor-related effects [9].

Chorioangiomas may act as peripheral arteriovenous shunts, leading to increased cardiac output, cardiomegaly and finally heart failure and hydrops, additionally complicated by fetal anemia in some cases [2-6]. When complications appear late in pregnancy, the best option is delivery. However, complications may appear earlier and delivery may be a problem due to fetal prematurity. Thus, different interventions have been proposed to prevent fetal loss related to large fetal chorioangioma complications. Amniodrainage for alleviating polyhydramnios $[3,5,7]$ and intrauterine transfusions in the presence of fetal anemia are two of the most common therapeutic procedures [7,10-12], although results are favorable, the problem that causes increased peripheral flow through the chorioangioma, it is not solved with amniodrainage or fetal transfusion. For that reason, other approaches have been used to stop vascular supply to the tumor and consequent heart failure. In addition to amniodrainage or fetal transfusion, different techniques have been used as injection of absolute alcohol [13-15], endoscopic laser coagulation [16,17], and interstitial laser therapy $[4,7]$, endoscopic suture with bipolar electrosurgery [18], and microcoil and embucrilate embolization, the last two procedures without survivors $[9,13,18]$. Table 1 summarize a literature review of therapy (excluding amniodrainage alone) and the presence/absence of hydrops as well as other complications in chorioangioma cases. When analysing the overall results of intraturine 
Table 1 Literature review of therapy (excluding amniodrainage alone), presence/absence of hydrops, and other complications in giant chorioangioma cases

\begin{tabular}{|c|c|c|c|c|c|c|c|}
\hline Reference & Case \# & $\begin{array}{l}\text { Greatest tumor } \\
\text { diameter }(\mathrm{mm})\end{array}$ & Hydrops & Other complications & Intrauterine therapy & $\begin{array}{l}\text { Delivery } \\
\text { (weeks) }\end{array}$ & $\begin{array}{l}\text { Pregnancy } \\
\text { outcome }\end{array}$ \\
\hline This report & 1 & 78 & Yes & $\begin{array}{l}\text { Polyhidramnios, } \\
\text { hydrothorax, mild } \\
\text { cardiomegaly, fetal } \\
\text { anemia, mirror } \\
\text { syndrome }\end{array}$ & $\begin{array}{l}\text { Intrauterine transfusion + } \\
\text { amniodrainage ( } 29 \text { weeks) }\end{array}$ & $29+6$ & Neonatal death \\
\hline Zanardini (2010) & 2 & 42 & No & $\begin{array}{l}\text { Polyhydramnios and } \\
\text { cardiomegaly }\end{array}$ & Fetoscopic laser (24+3 weeks) & $36+3$ & Live birth \\
\hline Zanardini (2010) & 3 & 45 & No & Moderate cardiomegaly & $\begin{array}{l}\text { Interstitial laser }(25+4 \\
\text { and } 26+4 \text { weeks) }\end{array}$ & $32+3$ & Live birth \\
\hline Zanardini (2010) & 4 & 35 & No & $\begin{array}{l}\text { Mild cardiomegaly } \\
\text { and fetal anemia }\end{array}$ & Interstitial laser (32+3 weeks) & $39+1$ & Live birth \\
\hline \multirow[t]{3}{*}{ Zanardini (2010) } & 5 & 54 & No & $\begin{array}{l}\text { Mild cardiomegaly } \\
\text { and fetal anemia }\end{array}$ & Amniodrainage ( $28+6$ weeks) & $37+3$ & Live birth \\
\hline & & & & & $\begin{array}{l}\text { Intrauterine blood } \\
\text { transfusion ( } 29 \text { weeks) }\end{array}$ & & \\
\hline & & & & & $\begin{array}{l}\text { Interstitial laser (29 and } \\
30+4 \text { weeks) }\end{array}$ & & \\
\hline Sisvali (2009) & 1 & 70 & Yes & Fetal anemia & $\begin{array}{l}\text { Intrauterine blood } \\
\text { transfusion at } 26\end{array}$ & 27 & Live birth \\
\hline \multirow{3}{*}{$\begin{array}{l}\text { Mendez-Figueroa } \\
\text { (2009) }\end{array}$} & 1 & 43 & Yes & Fetal anemia & Amniodrainage & 26 & Fetal demise \\
\hline & & & & & Intrauterine blood transfusion & & \\
\hline & & & & & $\begin{array}{l}\text { Fetoscopy: bipolar and } \\
\text { laser coagulation }\end{array}$ & & \\
\hline \multirow[t]{2}{*}{ Bermúdez (2007) } & 1 & 61 & Yes & Fetal anemia & Intrauterine blood transfusion. & 27 & Fetal demise \\
\hline & & & & & $\begin{array}{l}\text { Fetoscopic laser coagulation } \\
\text { Amniodrainage }\end{array}$ & & \\
\hline \multirow[t]{2}{*}{ Deren (2007) } & 1 & 83 & Yes & Fetal anemia & Intrauterine blood transfusion. & 28 & Live birth \\
\hline & & & & & $\begin{array}{l}\text { Alcohol injection into the } \\
\text { tumor ( } 25 \text { and } 26 \text { weeks) }\end{array}$ & & \\
\hline Quarello (2005) & 1 & 44 & Yes & No & $\begin{array}{l}\text { Fetoscopic laser coagulation } \\
\text { Amniodrainage }\end{array}$ & 39 & Live birth \\
\hline $\begin{array}{l}\text { Escribano D } \\
(2005)\end{array}$ & 1 & 81 & No & Fetal anemia & $\begin{array}{l}\text { Intrauterine blood transfusion } \\
(25 \text { weeks, } 60 \mathrm{ml})\end{array}$ & 39 & Live birth \\
\hline Lau (2005) & 1 & 90 & Yes & Polyhydramnios & $\begin{array}{l}\text { Ultrasound guided transcutaneous } \\
\text { embolisation with enbucrilate } \\
(24+2 \text { weeks })\end{array}$ & 26 & Neonatal death \\
\hline \multirow[t]{5}{*}{ Lau (2003) } & 1 & 74 & No & Fetal anemia & $\begin{array}{l}\text { Intrauterine blood transfusion } \\
\left(24^{\text {th }} \text { weeks, } 50 \mathrm{ml}\right)\end{array}$ & $29+6$ & Neonatal death \\
\hline & & & & & $\begin{array}{l}\text { Ultrasound-guided transcutaneous } \\
\text { embolisation with microcoil } \\
\text { (24+2th weeks, } 8 \text { pieces) }\end{array}$ & & \\
\hline & & & & & $\begin{array}{l}\text { Intrauterine blood transfusion } \\
\left(25^{\text {th }} \text { weeks, } 60 \mathrm{ml}\right)\end{array}$ & & \\
\hline & & & & & $\begin{array}{l}\text { Ultrasound-guided transcutaneous } \\
\text { embolisation with microcoil } \\
\text { (25th weeks, } 9 \text { pieces) }\end{array}$ & & \\
\hline & & & & & $\begin{array}{l}\text { Intrauterine blood transfusion } \\
\left(27^{\text {th }} 28^{\text {th }} 29 \text { th weeks }\right.\end{array}$ & & \\
\hline Sepúlveda (2003) & 1 & 75 & Yes & $\begin{array}{l}\text { Severe polyhydramnios } \\
\text { and cardiac faillure }\end{array}$ & Alcohol ablation (26 weeks) & 26 & $\begin{array}{l}\text { Fetal demise } \\
(26 \text { weeks) }\end{array}$ \\
\hline Nicolini (1999) & 1 & 60 & No & Polyhydramnios & Amniodrainage & $\mathrm{N} / \mathrm{A}$ & Live birth \\
\hline
\end{tabular}


Table 1 Literature review of therapy (excluding amniodrainage alone), presence/absence of hydrops, and other complications in giant chorioangioma cases (Continued)

\begin{tabular}{|c|c|c|c|c|c|c|c|}
\hline & & & & & Alcohol ablation (27 weeks) & & \\
\hline Nicolini (1999) & 2 & 50 & No & Polyhidramnios & $\begin{array}{l}\text { Alcohol ablation } \\
\text { ( } 24 \text { and } 25 \text { weeks) }\end{array}$ & N/A & Live birth \\
\hline Haak (1999) & 1 & 68 & No & $\begin{array}{l}\text { Fetal anemia } \\
\text { Polyhidramnios }\end{array}$ & $\begin{array}{l}\text { Intrauterine blood transfusion } \\
\text { (30 weeks, } 100 \mathrm{ml} \text { ) }\end{array}$ & 32 & Live birth \\
\hline Quintero (1996) & 1 & 85 & Yes & Fetal anemia & $\begin{array}{l}\text { Fetoscopy and devascularisation } \\
\text { by suture ligation and bipolar } \\
\text { cautery ( } 24^{\text {th }} \text { weeks) }\end{array}$ & $24+3$ & Fetal demise \\
\hline
\end{tabular}

interventions, it is also remarkable that mortality in cases without fetal hydrops is $10 \%$, while mortality in cases with fetal hydrops raises to $67 \%$. In fact, all successful intersticial laser procedures $[4,7]$ were performed to prevent the development of fetal hydrops.

Mirror syndrome (Ballantyne's syndrome) is usually defined as maternal edema associated to fetal hydrops [19]. Different fetal conditions have been related to mirror syndrome, although pathogenesis and pathofisiology of Ballantyne's syndrome is currently unknown [19]. Mirror syndrome associated to large placental chorioangiomas has been described only a few times [20-23] and maternal edema has been always present, as was in our case. In addition, other clinical markers also been reported as oliguria, anemia, elevated liver enzymes, hypoproteinemia and hypokalemia were also present in our patient. Additional clinical signs and symptoms described in Mirror syndrome related to large chorioangiomas such as elevated blood pressure, proteinuria, elevated uric acid and creatinine, headache and visual disturbances, and low platelets were absent in our case, which made easier differential diagnosis with preeclampsia. As described elsewhere [19] mirror syndrome disappears shortly after fetal hydrops successful treatment, pregnancy termination or delivery, as in the patient presented here.

\section{Conclusions}

In the case described here, which presented with fetal anemia and severe hydrops, additionally complicated by maternal mirror syndrome, intrauterine transfusion and amniodrainage were performed. However, fetal condition got worse despite of the anemia correction. Finally, an emergency cesarean section, after thoracocentesis to optimise the neonatal resuscitation, was performed due to worsening of maternal and fetal condition and to prevent fetal demise. Current data and experience from clinical practice are still scanty to support the effectiveness of intrauterine therapy procedures in chorioangioma complicated cases, specially in cases with fetal hydrops, which led us to attempt a more conservative approach. However, our outcome raises the issue whether additional intrauterine clinical intervention, as intersticial laser, should have been performed to stop further deterioration of the fetal condition when progressive severe hydrops develops.

\section{Consent}

Written informed consent was obtained from the patient for publication of this report and any accompanying images, as it is our usual publication policy according to our Internal Review Board instructions.

\section{Competing interests}

The authors declare that they have no competing interests.

\section{Authors' contributions}

GA and LG-D drafted the manuscript, and PC and SC-P collaborated with valuable contributions to the manuscript. All authors have read and approved the final manuscript.

\section{Author details}

${ }^{1}$ Unidad de Gestión Clínica de Genética, Reproducción y Medicina Fetal. Instituto de Biomedicina de Sevilla (IBIS), Hospital Universitario Virgen del Rocío/CSIC/Universidad de Sevilla, Sevilla, Spain. ${ }^{2}$ Servicio de Obstetricia y Ginecologia, Hospital Juan Ramón Jiménez, Huelva, Spain. ${ }^{3}$ Centro de Investigación Biomédica en Red de Enfermedades Raras (CIBERER), Sevilla, Spain. ${ }^{4}$ Director de la Unidad de Gestión Clínica de Genética, Reproducción y Medicina Fetal, Hospital de la Mujer, Hospital Universitario Virgen del Rocío, Avda. Manuel Siurot s/n, 41013, Sevilla, Spain.

Received: 23 November 2011 Accepted: 20 July 2012

Published: 28 July 2012

\section{References}

1. Fox H, Sebire NJ: Non-trophoblastic tumors of the placenta. In Pathology of the Placenta. 3rd edition. Edited by Fox H, Sebire N. Philadelphia: Saunders Elsevier; 2007:401-430.

2. Sepulveda W, Aviles G, Carstens E, Corral E, Perz N: Prenatal diagnosis of solid placental masses; the value of color flow imaging. Ultrasound Obstet Gynecol 2000, 16:554-558.

3. Sepulveda W, Alcalde JL, Schnapp C, Bravo M: Perinatal outcome after prenatal diagnosis of placental chorioangioma. Obstet Gynecol 2003, 102:1028-1033.

4. Bhide A, Prefumo F, Sairam S, Carvalho JS, Thilaganathan BT: Ultrasoundguided interstitial laser therapy for the treatment of placental chorioangioma. Obstet Gynecol 2003, 102:1189-1191.

5. Nicolini U, Zuliani G, Caravelli E, Fogliani R, Poblete A, Roberts A: Alcohol injection: a new method of treating placental chorioangiomas. Lancet 1999, 353:1674-1675.

6. Jauniaux E, Kadri R, Donner C, Rodesch F: Not all chorioangiomas are associated with elevated maternal serum alphafetoprotein. Prenat Diagn 1991, 11:73-74. 
7. Zanardini C, Papageorghiou A, Bhide A, Thilaganathan B: Giant placental chorioangioma: natural history and pregnancy outcome. Ultrasound Obstet Gynecol 2010, 35:332-336.

8. Quintero RA, Reich H, Romero R, Johnson MP, Goncalves L, Evans MI: In utero endoscopic devascularization of a large chorioangioma. Ultrasound Obstet Gynecol 1996, 8:48-52

9. Wehrens X, Offermans JPM, Snijders M, Peeters L: Fetal cardiovascular response to large placental Chorioangiomas J. Perinat Med 2004 32:107-112.

10. Sivaslı E, Tekşam Ö, Haliloğlu M, Güçer S, Orhan D, Gürgey A, Tekinalp G: Hydrops fetalis associated with chorioangioma and thrombosis of umbilical vein. Turk J Pediatr 2009, 51:515-518.

11. Haak MC, Oosterhof H, Mouw RJ, Oepkes D, Vandenbussche FPHA: Pathophysiology and treatment of fetal anemia due to placental chorioangioma. Ultrasound Obstet Gynecol 1999, 14:68-70.

12. Escribano D, Galindo A, Arbués J, Puente JM, De la Fuente P: Prenatal management of placental chorioangioma: value of the middle cerebral artery peak systolic velocity. Fetal Diagn Ther 2006, 21:489-493.

13. Lau TK, Yu SCH, Leung TY, To KF, Fung TY, Leung TN: Prenatal embolisation of a large chorioangioma using enbucrilate. BJOG 2005, 112:1002-1004.

14. Wanapirak C, Tongsong T, Sirichotiyakul S, Chanprapapah P: Alcoholization: the choice of intrauterine treatment for chorioangioma. J Obstet Gynaecol Res 2002, 28:71-75.

15. Deren O, Ozyuncu O, Onderoglu LS, Durukan T: Alcohol injection for the intrauterine treatment of chorioangioma in a pregnancy with transfusion resistant fetal anemia: a se report. Fetal Diagn Ther 2007, 22:203-205.

16. Bermudez C, Luengas O, Perez-Wulff J, Genatios U, Garcia V, GuevaraZuloaga F, Quintero RA: Management of a placental chorioangioma with endoscopic devascularization and intrauterine transfusions. Ultrasound Obstet Gynecol 2007, 29:97-98.

17. Quarello E, Bernard JP, Leroy B, Ville Y: Prenatal laser treatment of a placental chorioangioma. Ultrasound Obstet Gynecol 2005, 25:299-301.

18. Mendez-Figueroa H, Papanna R, Popek EJ, Byrd RH, Goldaber K, Moise KJ, Jonson A: Endoscopic laser coagulation following amnioreduction for the management of a large placental chorioangioma. Prenat Diagn 2009, 29:1277-1278

19. Braun T, Brauer M, Fuchs I, Czernik C, Dudenhausen J, Henrich W, Sarioglu N: Mirror Syndrome: A Systematic Review of Fetal Associated Conditions, Maternal Presentation and Perinatal Outcome. Fetal Diagn Ther 2010 27:191-203.

20. Dorman SL, Cardwell MS: Ballantyne syndrome caused by a large placental chorioangioma. Am J Obstet Gynecol 1995, 173:1632-1633.

21. Gherman RB, Incerpi MH, Wing DA, Goodwin TM: Ballantyne syndrome: is placental ischemia the etiology? J Matern Fetal Med 1998, 7:227-229.

22. Galimberti A, Jain S: Placental chorioangioma as a cause of maternal hydrops syndrome. J Obstet Gynaecol 2000, 20:91.

23. Zoppini C, Acaia B, Lucci G, Pugni L, Tassis B, Nicolini U: Varying Clinical Course of large Placental Chorioangiomas. Report of 3 cases. Fetal Diagn Ther 1997, 12:61-64.

doi:10.1186/1471-2393-12-72

Cite this article as: García-Díaz et al:: Prenatal management and perinatal outcome in giant placental chorioangioma complicated with hydrops fetalis, fetal anemia and maternal mirror syndrome. $B M C$ Pregnancy and Childbirth 2012 12:72.

\section{Submit your next manuscript to BioMed Central and take full advantage of:}

- Convenient online submission

- Thorough peer review

- No space constraints or color figure charges

- Immediate publication on acceptance

- Inclusion in PubMed, CAS, Scopus and Google Scholar

- Research which is freely available for redistribution 